ORIGINAL RESEARCH ARTICLE

\title{
Allelopathic effect of Pinus roxburghii on an understorey plant, Bidens pilosa
}

Neel Kant Sharma ${ }^{1 *}$, Daizy R. Batish ${ }^{1}$, Harminder Pal Singh ${ }^{2}$ and R. K. Kohli ${ }^{1,3}$

${ }^{1}$ Department of Botany, Panjab University, Chandigarh 160014, India.

2Department of Environment Studies, Panjab University, Chandigarh 160014, India.

${ }^{3}$ Central University of Punjab, Bathinda 151001, India.

Received: September 11, 2016; Revised: September 19, 2016; Accepted: October 29, 2016

\begin{abstract}
Allelopathic effect of Pinus roxburghii was studied on Bidens pilosa through laboratory and greenhouse experiments. The aqueous extracts of green needles, needle litter and bark were found to inhibit germination and initial growth of B. pilosa in laboratory bioassays. The inhibitory effect on germination root length, shoot length and biomass was also observed on amendment of powdered needle litter in soil in greenhouse pots. The inhibitory effect increased with increase in conc. of extracts or amount of litter amended. The amended soil was found to be rich in phenolics, the known potent allelochemics. The study indicates that such interactions may also be operational in forests of P. roxburghii.
\end{abstract}

Key words: Allelopathy; Aqueous extracts; Needles; Phenolics; Pinus roxburgbii

\section{Introduction}

Allelopathy refers to the effect of one plant on the other through the release of chemical substances (Rice, 1984). These chemicals are released through volatilization, leaching, as root exudates, or as a result of decomposition of plant residues (Rice, 1984). The allelochemicals, upon release, undergo a variety of changes such as sorption, transformation, toxification and / or detoxification (Cheng, 1992; Blum et al., 1999). However, their effect depends greatly upon a variety of biotic and abiotic factors, soil type, presence of microorganisms and soil conditions (Blum et al., 1999). Allelopathy is an important ecological phenomenon and governs plant-plant interaction (Kim et al., 1997). It plays a significant role in vegetation dynamics and is partially responsible for success or failure of seedling establishment and survival in forest ecosystems (Pellissier and Souto, 1999). This process has been demonstrated to be capable of altering the structure, function, and diversity of plant communities (Muller, 1969; Whittaker, 1970). The complexity and interacting nature of allelopathic phenomena make it difficult to demonstrate its role in plant interactions and community organization (Zen, 2014). So, in most cases, the assessments of allelopathy have been done through bioassays of plant or soil extracts based on seed germination or seedling growth.

The present study was undertaken to assess the allelopathic effects of needle (foliage), needle litter and bark of Pinus roxburghii Sargent (commonly known as Chir Pine) on early growth of Bidens pilosa L., an understorey plant. $P$. roxburghii is native to the Himalayas and one of the important forestry trees.

\section{Materials and Methods \\ Collection of Plant Material}

The needles (foliage), needle litter (undecomposed) and bark of $P$. roxburghii were collected from a forest of Mandi district of Himachal Pradesh, shade dried and powdered in electrical grinder. The seeds of test plant, B. pilosa were collected from plants growing in wild in surrounding areas.

\section{Laboratory bioassays}

Aqueous extract were prepared from powder of needles, needle litter and bark. For this, 4 grams of needle powder was soaked in $100 \mathrm{ml}$ of distilled water for 18 hours at room temperature. The contents were filtered through triple layered muslin cloth followed by Whatman No. 1 filter paper. This $4 \%(\mathrm{w} / \mathrm{v})$ stock solution was further diluted to get lower concentration of $0.5,1$ and $2 \%$. Pure distilled water served as control. 15 seeds of B. pilosa were placed in $15 \mathrm{~cm}$ diameter Petri dish, lined with filter paper and moistened with $10 \mathrm{ml}$ of respective solution or distilled water (control). The effect of different concentrations was studied on germination and initial growth of B. pilosa. For each treatment, 5 replicates were maintained. The percent germination, root length, shoot length and biomass of seedlings were recorded after a week.

\section{Greenhouse experiment}

The needle litter powder of $P$. roxburghii was mixed in the ratio of $0,5,10,20$ and 40 grams of powder per kilogram of soil in pots. 15 seeds of Bidens pilosa were sown in each pot. After germination thinning of seedling was done to 5 plants per pot. The pots were watered regularly. The percent emergence, root length, shoot length and biomass of test plant

\footnotetext{
${ }^{*}$ Corresponding Author:

Neel Kant Sharma,

Research Scholar,

Department of Botany,

Panjab University, Chandigarh, India.

E- mail: neelkantsharma23@gmail.com
}

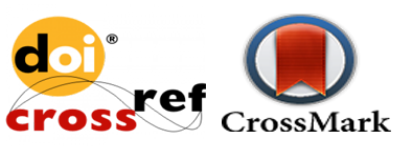


were recorded after one month. Powder amended soil was analyzed for presence of phenolics as per Swain and Hillis (1959) after one month of amendment. Five replicates were maintained for each treatment. The replicates were kept in completely randomized manner.

\section{Statistical analysis}

The data were analyzed by one- way ANOVA at $\mathrm{p} \leq$ 0.05 applying post-hoc Tukey's test. The statistical analysis was performed using SPSS/PC software ver. 16.0 (SPSS Inc., Chicago, IL).

\section{Results and Discussion}

Different species of Pinus and other conifers have been reported to cause allelopathic effects on other species (Lodhi and Killingbeck, 1982; Kil and Yim, 1983; Kil et al., 1991; Kil, 1992; Gallet, 1994; Singh et al., 1999b; Kato-Noguchi et al., 2009; Refifa et al. 2016). Melkania et al. (1982) have reported the allelopathic effects of leachates / extracts of $P$. roxburgii on some crop plants.

In our study, the germination and growth of test plant were affected adversely, in both laboratory bioassays as well as litter amended pot experiment. The percent germination, in general, was significantly affected at extract concentration of $1 \%$ and above. In general, the effect of green needles and litter extracts was almost similar whereas the bark extracts had slightly more inhibitory effect on germination (Table 1). The reduction in germination of target species in response to leaf and litter extracts of conifers has been reported by Jobidon (1986). The bark extracts of Picea engelmannii inhibited the seed germination of own and other conifers (Taylor and Shaw, 2011). Valera-Burgos et al. (2012) reported the negative effects of Pinus pinea litter on seed germination and seedling performance of three Mediterranean shrub species.

Wu et al. (2011) reported the allelopathic inhibition in germination and growth of herbaceous species in response to extracts of tree Eucalyptus dundasii. The inhibition of seed germination and seedling growth of target species in response to leaf litter extracts of Ulmus pumila, containing phenolics was reported by Pérez-Corona et al. (2013). In our study decrease in root length, shoot length and biomass of seedlings (Table 2, 3 and 4) was observed in concentration dependent manner in all three types of extracts. The overall response to needle and needle litter extracts were almost similar. However, the bark extracts were found to be slightly more toxic as compared to these two.

Table 1: Effect of green needle extract (GNE), needle litter extract (NLE) and bark extract (BE) of Pinus roxburghii on germination of Bidens pilosa

\begin{tabular}{cccc}
\hline \multirow{2}{*}{ Concentration (\%) } & \multicolumn{3}{c}{ Germination (\%) } \\
\cline { 2 - 4 } & Green Needle & Needle Litter & Bark \\
\hline 0 & $98.66 \pm 1.33 \mathrm{a}(0)$ & $98.66 \pm 1.33 \mathrm{a}(0)$ & $98.66 \pm 1.33 \mathrm{a}(0)$ \\
0.5 & $90.66 \pm 2.66 \mathrm{ab}(8.1)$ & $91.99 \pm 2.49 \mathrm{ab}(6.8)$ & $89.32 \pm 1.63 \mathrm{~b}(9.5)$ \\
1.0 & $81.33 \pm 3.88 \mathrm{~b}(17.6)$ & $82.66 \pm 2.66 \mathrm{~b}(16.2)$ & $75.99 \pm 1.63 \mathrm{c}(23.0)$ \\
2.0 & $70.66 \pm 1.63 \mathrm{c}(28.4)$ & $69.32 \pm 1.63 \mathrm{c}(29.3)$ & $63.99 \pm 2.66 \mathrm{~d}(35.1)$ \\
4.0 & $55.93 \pm 3.34 \mathrm{~d}(43.3)$ & $57.26 \pm 2.60 \mathrm{~d}(42.0)$ & $49.32 \pm 1.63 \mathrm{e}(50.0)$ \\
\hline
\end{tabular}

Data presented as mean \pm standard error

Different alphabets within a column represent significant difference among treatments at $\mathrm{p} \leq 0.05$ applying post hoc Tukey's test Values within parenthesis represent percent decrease over the control

Table 2: Effect of green needle extract (GNE), needle litter extract (NLE) and bark extract (BE) of Pinus roxburghii on root length of Bidens pilosa

\begin{tabular}{cccc}
\hline \multirow{2}{*}{ Concentration (\%) } & \multicolumn{3}{c}{ Root Length (cm) } \\
\cline { 2 - 4 } & Green Needle & Needle Litter & Bark \\
\hline 0 & $3.05 \pm 0.11 \mathrm{a}(0)$ & $3.05 \pm 0.11 \mathrm{a}(0)$ & $3.05 \pm 0.11 \mathrm{a}(0)$ \\
0.5 & $2.83 \pm 0.04 \mathrm{a}(7.2)$ & $2.78 \pm 0.06 \mathrm{a}(8.9)$ & $2.65 \pm 0.06 \mathrm{~b}(13.1)$ \\
1.0 & $2.40 \pm 0.07 \mathrm{~b}(21.3)$ & $2.39 \pm 0.06 \mathrm{~b}(18.9)$ & $2.26 \pm 0.06 \mathrm{c}(25.9)$ \\
2.0 & $1.73 \pm 0.07 \mathrm{c}(43.3)$ & $1.86 \pm 0.05 \mathrm{c}(39.0)$ & $1.77 \pm 0.06 \mathrm{~d}(42.0)$ \\
4.0 & $1.13 \pm 0.05 \mathrm{~d}(63.0)$ & $1.21 \pm 0.04 \mathrm{~d}(60.3)$ & $1.04 \pm 0.04 \mathrm{e}(65.9)$ \\
\hline
\end{tabular}

Data presented as mean \pm standard error

Different alphabets within a column represent significant difference among treatments at $\mathrm{p} \leq 0.05$ applying post hoc Tukey's test Values within parenthesis represent percent decrease over the control

Table 3: Effect of green needle extract (GNE), needle litter extract (NLE) and bark extract (BE) of Pinus roxburghii on shoot length of Bidens pilosa

\begin{tabular}{cccc}
\hline \multirow{2}{*}{ Concentration (\%) } & \multicolumn{3}{c}{ Shoot length (cm) } \\
\cline { 2 - 4 } & Green Needle & Needle Litter & Bark \\
\hline 0 & $4.02 \pm 0.06 \mathrm{a}(0)$ & $4.02 \pm 0.06 \mathrm{a}(0)$ & $4.02 \pm 0.06 \mathrm{a}(0)$ \\
0.5 & $3.81 \pm 0.07 \mathrm{a}(5.2)$ & $3.79 \pm 0.06 \mathrm{a}(5.7)$ & $3.51 \pm 0.09 \mathrm{~b}(12.7)$ \\
1.0 & $3.02 \pm 0.07 \mathrm{~b}(24.9)$ & $2.98 \pm 0.05 \mathrm{~b}(25.9)$ & $2.79 \pm 0.09 \mathrm{c}(35.1)$ \\
2.0 & $2.38 \pm 0.09 \mathrm{c}(40.8)$ & $2.27 \pm 0.07 \mathrm{c}(43.5)$ & $2.16 \pm 0.06 \mathrm{~d}(46.26)$ \\
4.0 & $1.74 \pm 0.06 \mathrm{~d}(56.7)$ & $1.65 \pm 0.06 \mathrm{~d}(59)$ & $1.34 \pm 0.07 \mathrm{e}(66.7)$
\end{tabular}

Data presented as mean \pm standard error

Different alphabets within a column represent significant difference among treatments at $\mathrm{p} \leq 0.05$ applying post hoc Tukey's test

*Figures within parenthesis represent percent decrease over the control 
Table 4: Effect of green needle extract (GNE), needle litter extract (NLE) and bark extract (BE) of Pinus roxburghii on seedling biomass of Bidens pilosa

\begin{tabular}{cccc}
\hline \multirow{2}{*}{ Concentration (\%) } & \multicolumn{3}{c}{ Biomass (mg) } \\
\cline { 2 - 4 } & Green Needle & Needle Litter & Bark \\
\hline 0 & $0.98 \pm 0.02 \mathrm{a}(0)$ & $0.98 \pm 0.02 \mathrm{a}(0)$ & $0.98 \pm 0.02 \mathrm{a}(0)$ \\
0.5 & $0.90 \pm 0.03 \mathrm{ab}(8.2)$ & $0.92 \pm 0.02 \mathrm{a}(6.1)$ & $0.86 \pm 0.02 \mathrm{~b}(12.2)$ \\
1.0 & $0.81 \pm 0.01 \mathrm{bc}(17.3)$ & $0.84 \pm 0.03 \mathrm{ab}(14.3)$ & $0.75 \pm 0.01 \mathrm{~b}(23.5)$ \\
2.0 & $0.72 \pm 0.01 \mathrm{~cd}(26.5)$ & $0.70 \pm 0.01 \mathrm{bc}(28.6)$ & $0.61 \pm 0.01 \mathrm{c}(37.8)$ \\
4.0 & $0.62 \pm 0.01 \mathrm{~d}(36.7)$ & $0.59 \pm 0.04 \mathrm{c}(39.8)$ & $0.47 \pm 0.04 \mathrm{~d}(52.0)$
\end{tabular}

Data presented as mean \pm standard error

Different alphabets within a column represent significant difference among treatments at $\mathrm{p} \leq 0.05$ applying post hoc Tukey's test

Values within parenthesis represent percent decrease over the control

Litter decomposition is claimed to be the most important source of allelochemical release (Reigosa et al., 1996). P. roxburgbii forest floor is characterized by a carpet of fallen needles. The understorey of chir pine forests is characterized by sparse vegetation, which could possibly be due to allelopathic effect, at least partially. In our pot culture experiment, which was an attempt to simulate the natural conditions in $P$. roxburghii forests, the germination and growth of test plant were affected adversely in powder amended soil medium in all treatments as compared to control (Table 5). The germination and growth inhibition increased with increase in amount of litter powder amended. Kil and Yim (1983) reported that toxic substances released from Pinus densiflora inhibit seed germination and growth of other species in the forest. The phenolic compounds extracted from the aqueous extracts of Pinus rigida showed both inhibitory and stimulatory effect on Cassia mimosoides var. nomame depending upon the concentration (Kim et al., 1997). However, in our study all concentrations showed inhibitory effect. Kil (1992) demonstrated that growth of understorey plants was inhibited in soil mixed with pine needles. He attributed the growth inhibition of understorey plants to water soluble phenolics. He indicated that the allelochemicals may also affect indirectly by altering the symbiotic relationships with microorganisms, rhizosphere ecology and nutrient availability.

Soil analysis revealed the presence of water soluble phenolics in powder amended soil (Figure). The amount of total water soluble phenolics increased with increase in the dose of powder. The total phenolic content detection is relevant as phenolics act synergistically (Williams and Hoagland, 1982). These compounds affect plant growth directly or by altering the other properties of soil (Blum et al., 1999). Although the amount of phenolics measured in amended soil increased with increase in amount of amended powder, however it was not exactly proportional to amount of powder amended indicating the role of biotic factors (soil microorganisms) in toxification or detoxification. Singh et al.(1999a) attributed the presence of phenolics in litter and leaves of Leucaena leucocephala for observed inhibitory effect on Zea mays. The inhibitory effects observed in present study can also be attributed mainly to the water soluble phenolics, an important class of allelochemicals.

Table 5: Effect of Pinus roxburghii needle litter amended soil on seedling emergence and growth of Bidens pilosa

\begin{tabular}{ccccc}
\hline $\begin{array}{c}\text { Litter amended } \\
\text { ( } \text { kg-1 }^{-1} \text { soil) }\end{array}$ & Seedling emergence (\%) & Root length $\mathbf{( c m )}$ & Shoot length $\mathbf{( c m )}$ & Biomass (mg) \\
\hline 0 & $97.33 \pm 1.63 \mathrm{a}(0)$ & $18.79 \pm 0.41 \mathrm{a}(0)$ & $12.37 \pm 0.22 \mathrm{a}(0)$ & $148.72 \pm 2.83 \mathrm{a}(0)$ \\
5 & $87.99 \pm 2.49 \mathrm{a}(-9.6)$ & $19.09 \pm 0.39 \mathrm{a}(+1.6)$ & $10.83 \pm 0.25 \mathrm{~b}(-12.44)$ & $138.88 \pm 2.19 \mathrm{~b}(-6.6)$ \\
10 & $73.32 \pm 3.65 \mathrm{~b}(-24.7)$ & $13.16 \pm 0.26 \mathrm{~b}(-30.0)$ & $8.89 \pm 0.17 \mathrm{c}(-28.13)$ & $89.62 \pm 1.51 \mathrm{c}(-39.7)$ \\
20 & $59.99 \pm 3.65 \mathrm{c}(-38.4)$ & $7.91 \pm 0.24 \mathrm{c}(-57.9)$ & $5.95 \pm 0.18 \mathrm{~d}(-51.9)$ & $28.40 \pm 1.85 \mathrm{~d}(-80.9)$ \\
40 & $46.66 \pm 2.10 \mathrm{~d}(-52.1)$ & $4.27 \pm 0.11 \mathrm{~d}(-77.3)$ & $4.14 \pm 0.08 \mathrm{e}(-66.5)$ & $9.56 \pm 0.22 \mathrm{e}(-93.6)$
\end{tabular}

Data presented as mean \pm standard error;

Different alphabets within a column represent significant difference among treatments at $\mathrm{p} \leq 0.05$ applying post hoc Tukey's test; Values within parenthesis represent percent increase $(+)$ or decrease $(-)$ over the respective control.

Figure: Total water soluble phenolic content in soil amended with Pinus roxburghii needle litter powder.

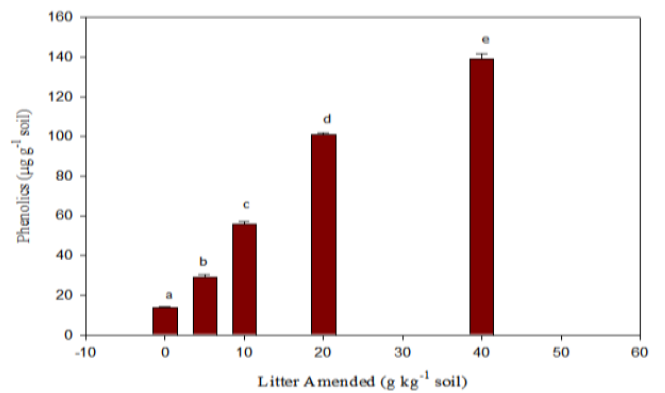

Vertical bars represent standard error

Different alphabets represent significant difference among treatments at $\mathrm{p} \leq 0.05$ applying post hoc Tukey's test

\section{Conclusions}

The study concludes that $P$. roxburghii possesses allelopathic potential and affects the growth of under storey plant, B. pilosa in laboratory and greenhouse conditions. The present study indicates that similar allelopathic interactions might be occurring in plantations and natural forests of $P$. roxburghii. Allelopathy seems to be an important factor in determining the vegetation structure of these forests. 


\section{References}

1. Blum, U., S.R. Shafer and M.E. Lehman. "Evidence for inhibitory allelopathic interactions involving phenolic acids in field soils: concepts vs. an experimental model." Critical Reviews in Plant Sciences 18 (1999): 673693.Print.

2. Cheng, H.H. "A conceptual framework for assessing allelochemicals in the soil environment." In: S.J.H. Rizvi and V. Rizvi (ed.) Allelopathy: Basic and Applied Aspects. Chapman and Hall Publisher, UK (1992): 21 29. Print.

3. Gallet, C. "Allelopathic potential in bilberryspruce forests, influence of phenolic compounds on spruce seedlings." Journal of Chemical Ecology 20 (1994): 1009-1024.Print.

4. Jobidon, R. "Allelopathic potential of coniferous species to old- field weeds in Eastern Quebec.” Forest science 32 (1986): 112118.Print.

5. Kato-Noguchi, H., Y. Fushimi and H. Shigemori. "An allelopathic substance in red pine needles (Pinus densiflora)." Journal of Plant Physiology 166 (2009): 442-446.Print.

6. Kil, B. S. "Effect of pine allelochemicals on selected species in Korea." In: S.J.H. Rizvi and V. Rizvi (ed.) Allelopathy: Basic and Applied Aspects. Chapman and Hall Publisher, UK (1992): 205-241.Print.

7. Kil, B.S., and Y.J. Yim. "Allelopathic effects of Pinus densiflora on undergrowth of Red Pine Forest." Journal of Chemical Ecology 9 (1983): 1135-1151.Print.

8. Kil, B.S., D. Y. Kim, Y.S. Kim and S.Y. Lee. "Phytotoxic effects of naturally occurring chemicals from Pinus koraiensis on experimental species." Korean Journal of Ecology 14 (1991):149157.Print.

9. Kim, Y.O., H.J. Lee and N. K. Chang. "Effects of Pinus rigida allelochemicals on isozyme activities during seed germination of Cassia mimosoides var. nomame." Korean Journal of Ecology 20 (1997):103-109.Print.

10. Lodhi, M.A.K., and K.T. Killingbeck. "Effect of pine produced chemicals on selected understory species in a Pinus ponderosa community." Journal of Chemical Ecology 8 (1982): 275-283.Print.

11. Melkania, N.P., J.S. Singh and K.K.S. Bisht. "Allelopathic potential of Artemisia vulgaris L. and Pinus roxburghii Sargent: A bioassay study." Proceedings of Indian National Science Academy Part B 48 (1982): 685-688.Print.

12. Muller, C.H. "Allelopathy as a factor in ecological process." Vegetation 18 (1969):348357.Print.

13. Pellissier, F., and X.C. Souto. "Allelopathy in northern temperate and boreal semi-natural woodland." Critical Reviews in Plant Sciences 18.5 (1999): 637-652.Print.

14. Pérez-Corona, M.E., P. De lash eras and B. R. Vazquez de Aldana. "Allelopathic potential of invasive Ulmus pumila on understory plant species." Allelopathy Journal 32 (2013): 101112.Print.

15. Refifa, T., H. Chahdoura, G. Flamini, K. Adouni, L. Achour and A. Helal. "Allelopathic potential of Pinus halepensis needles." Allelopathy Journal 38.1 (2016): 103-124.Print.

16. Reigosa, M.J., X.C. Souto and L. Gonzalez. "Allelopathy research: Methodological, ecological and ecolutionary aspects." In: Allelopathy, Field observations and Methodology. Narwal, S.S. and Tauro, P. (Eds.). Scientific Publishers, Jodhpur 1 (1996): 213-231.Print.

17. Rice, E.L. Allelopathy, $2^{\text {nd }}$ edition, Academic Press, Orlando, Florida, USA (1984). Print.

18. Singh, H.P., D. R. Batish and R. K. Kohli. "Allelopathic effect of Leucaena leucocephala on Zea mays." Journal of Tropical Forest Science 11.4 (1999a): 801-808. Print.

19. Singh, H.P., R. K. Kohli, D. R. Batish and P. S. Kaushal. "Allelopathy of Gymnospermous trees." Journal of Forest Research 4 (1999b): 245254.Print.

20. Swain, T. and W. E. Hillis. "The phenolic constituents of Prunus domestica I.-The quantitative analysis of constituents." Journal of the Science of Food and Agriculture 10 (1959): 6368. Print.

21. Taylor, R.J. and D.C. Shaw. "Allelopathic effects of Engelmann spruce bark stibenes and tannin-stibene combinations on seed germination and seedling growth of selected conifers." Canadian Journal of Botany 61.1 (2011): 279-289.Print.

22. Valera-Burgos, J., M. C. Diaz-Barradas and M. Zunzunegui. "Effects of Pinus pinea litter on seed germination and seedling performance of three Mediterranean shrub species." Plant Growth Regulation 66 (2012): 285-292.Print. 
23. Whittaker, R.H. "The biochemical ecology of higher plants." In: E. Sondheimer and J.B. Simeone (Eds.) Chemical Ecology, Academic Press, N.Y. (1970): 43-70. Print.

24. Williams, R. D. and R. E. Hoagland. "The effects of naturally occurring phenolic compounds on seed germination." Weed Science 30 (1982): 206-212.Print.

25. Wu, H.W., J.B. Zhang, R. Stanton, M. An, D.L. Liu and D. Lemerle. "Allelopathic effects of Eucalyptus dundasii on germination and growth of ryegrass and barley grass." Allelopathy Journal 28 (2011): 87-94. Print.

26. Zen, R.S. "Allelopathy: the solution is indirect." Journal of Chemical Ecology 40 (2014): 515- 516.Print.

\section{Cite this article as:}

Neel Kant Sharma, Daizy R. Batish, Harminder Pal Singh and R. K. Kohli. Allelopathic effect of Pinus roxburgbii on an understorey plant, Bidens pilosa. Annals of Plant Sciences 5.9 (2016): 1446-1450.

DOI: http://dx.doi.org/10.21746/aps.2016.10.005

Source of support: PU, Chandigarh.

Conflict of interest: None Declared 